\title{
Article \\ Erinacine A-Enriched Hericium erinaceus Mycelium Delays Progression of Age-Related Cognitive Decline in Senescence Accelerated Mouse Prone 8 (SAMP8) Mice
}

\author{
Li-Ya Lee ${ }^{1}$, Wayne Chou ${ }^{2}$, Wan-Ping Chen ${ }^{2}$, Ming-Fu Wang ${ }^{3}$, Ying-Ju Chen ${ }^{4}$, Chin-Chu Chen ${ }^{5,6,7}$ \\ and Kwong-Chung Tung ${ }^{1, *}$
}

Citation: Lee, L.-Y.; Chou, W.; Chen, W.-P.; Wang, M.-F.; Chen, Y.-J.; Chen, C.-C.; Tung, K.-C. Erinacine

A-Enriched Hericium erinaceus Mycelium Delays Progression of Age-Related Cognitive Decline in Senescence Accelerated Mouse Prone 8 (SAMP8) Mice. Nutrients 2021, 13, 3659. https://doi.org/10.3390/ nu13103659

Academic Editor: Maria Antonietta Panaro

Received: 9 September 2021 Accepted: 14 October 2021 Published: 19 October 2021

Publisher's Note: MDPI stays neutral with regard to jurisdictional claims in published maps and institutional affiliations.

Copyright: (c) 2021 by the authors. Licensee MDPI, Basel, Switzerland. This article is an open access article distributed under the terms and conditions of the Creative Commons Attribution (CC BY) license (https:/ / creativecommons.org/licenses/by/ $4.0 /)$.
1 Department of Veterinary Medicine, National Chung Hsing University, Taichung 402204, Taiwan; liya5237@gmail.com

2 Biotech Research Institute, Grape King Bio Ltd., Taoyuan 325002, Taiwan; Wayne.Chou@grapeking.com.tw (W.C.); WP.Chen@grapeking.com.tw (W.-P.C.)

3 Department of Food and Nutrition, Providence University, Taichung 433303, Taiwan; mfwang@pu.edu.tw

4 College of Humanities \& Social Sciences, Providence University, Taichung 433303, Taiwan; yjchen5@pu.edu.tw

5 Institute of Food Science and Technology, National Taiwan University, Taipei 106319, Taiwan; gkbioeng@grapeking.com.tw

6 Department of Food Science, Nutrition and Nutraceutical Biotechnology, Shih Chien University, Taipei 104336, Taiwan

7 Department of Bioscience Technology, Chung Yuan Christian University, Taoyuan 320314, Taiwan

* Correspondence: kctung1@dragon.nchu.edu.tw

\begin{abstract}
There have been many reports on the neuroprotective effects of Hericium erinaceus mycelium, in which the most well-known active compounds found are diterpenoids, such as erinacine A. Previously, erinacine A-enriched Hericeum erinaceus mycelium (EAHEM) was shown to decrease amyloid plaque aggregation and improve cognitive disability in Alzheimer's disease model APP/PS1 mice. However, its effects on brain aging have not yet been touched upon. Here, we used senescence accelerated mouse prone 8 (SAMP8) mice as a model to elucidate the mechanism by which EAHEM delays the aging of the brain. Three-month-old SAMP8 mice were divided into three EAHEM dosage groups, administered at 108, 215 and $431 \mathrm{mg} / \mathrm{kg} / \mathrm{BW} /$ day, respectively. During the 12th week of EAHEM feeding, learning and memory of the mice were evaluated by single-trial passive avoidance and active avoidance test. After sacrifice, the amyloid plaques, induced nitric oxidase synthase (iNOS) activity, thiobarbituric acid-reactive substances (TBARS) and 8-OHdG levels were analyzed. We found that the lowest dose of $108 \mathrm{mg} / \mathrm{kg} / \mathrm{BW}$ EAHEM was sufficient to significantly improve learning and memory in the passive and active avoidance tests. In all three EAHEM dose groups, iNOS, TBARS and 8-OHdG levels all decreased significantly and showed a dose-dependent response. The results indicate that EAHEM improved learning and memory and delayed degenerative aging in mice brains.
\end{abstract}

Keywords: Hericium erinaceus; senescence accelerated mouse prone 8 (SAMP8); aging; memory

\section{Introduction}

With the advent of an aging population worldwide, neurodegenerative diseases have become a major socioeconomic concern, of which Alzheimer's Disease (AD) is most closely tied to aging. Currently, there are no clinically effective drugs that can cure AD. Rather, a reasonable retardation of its progression can be achieved [1]. A preventive angle for treatment is thus preferred, wherein intervention may be done before the diagnosis of mild dementia [2]. A strategy that would be more readily acceptable to the public is dietary supplements that provide preventive effects against the disease.

The world's population is aging, with epidemiological studies predicting an increase in the percentage of people over age 60 from $11 \%$ presently to $22 \%$ in 2050 [3]. Presently, 
the molecular pathogenesis of AD is not yet completely elucidated, adding to the concern of AD becoming a major health as well as economic crisis [4]. The overarching aims of research on brain aging include, (i) understanding how the brain changes with respect to age, (ii) understanding the causation of these changes, (iii) helping to improve brain health and decrease the detrimental effects of cognitive impairment and neuropsychiatric diseases during the course of aging [5-7].

SAMP8 is a proven animal model used to study the genetic mechanisms behind learning and memory impairment in the life cycle. For example, it has been used to show that excess amyloid aggregation in the early stages of life causes learning and memory impairment and disability [6,7]. The lion's mane mushroom (Hericeum erinaceus) is a popular species of edible mushroom in Eastern countries, such as China, Japan, Malaysia, Singapore and Taiwan, where they are consumed for both their culinary and medicinal values. Research on its putative benefits is mainly divided into two directions. Firstly, their polysaccharides have been revealed to possess tumor suppressive and immune boosting qualities [8-10]. The second direction of interest is diterpenoids, including the erinacines found only in liquid cultured mycelium, which have been found to stimulate glial cells to excrete nerve growth factor (NGF) [11-14]. In 2005, Japanese researchers conducted the first animal trials using erinacine A, showing its ability to increase NGF levels in the locus coeruleus and the hippocampus. This confirms erinacine A affects the central nervous system [15].

In recent years, there has been a considerable amount of research from Taiwan into the effects of Erinacine A-enriched Hericium erinaceus mycelia (EAHEM) in protecting against neurological disorders. In an animal model of ischemic stroke, feeding with 50 and $300 \mathrm{mg} / \mathrm{kg}$ body weight of EAHEM reduced the ratio of cerebral infarction by approximately 22 and 44 percent, respectively [16]. In an MPTP-induced model of Parkinson's disease, feeding low doses of EAHEM increased dopamine and NGF levels in the brain approximately 1.82- and 1.58-fold, respectively [17]. Five-month-old APP/PS1 transgenic mice fed with EAHEM at a dose of $300 \mathrm{mg} / \mathrm{kg} /$ day for 30 days were found to possess decreased $A \beta$ plaque burden, increased NGF/proNGF ratio and increased insulin degrading enzyme (IDE) levels. In the nest building assay, feeding of EAHEM yielded significant differences in score and unshredded cotton [18].

The above animal studies confirmed the protective effects of EAHEM on the brain in both neurotoxin-induced and physically-induced brain disorders. However, direct beneficial effects in the setting of brain degeneration as a result of aging has not been studied before. Therefore, this study aims to assess the brain aging, learning and memory conditions in an aging mouse model fed with EAHEM.

\section{Materials and Methods}

\subsection{Experimental Animals}

The animals used in this study were 3-month-old male and female senescence accelerated mice (SAMP8). Mice were housed in clear plastic cages of $30 \mathrm{~cm}$ (W) by $20 \mathrm{~cm}$ (D) by $10 \mathrm{~cm}(\mathrm{H})$ size. Mice were kept in a clean room maintained at a controlled temperature of $25 \pm 2{ }^{\circ} \mathrm{C}$, relative humidity of $65 \pm 5 \%$ and with automatically controlled light-dark cycle. The dark period lasted from 07:00 to 19:00, and the light period was from 19:00 to 07:00. Feed and water were given ad libitum. SAMP8 mice used in this study were an age-accelerated strain of mice developed by the University of Kyoto. The animals in this study were bred and kept at Ching-Yi University. Experiments in this study were approved by the IACUC (\#20120918-P04). Mice were randomly housed in groups of 4 per cage.

\subsection{Mycelium Preparation}

H. erinaceus strain (BCRC 35669) was obtained from the Bioresources Collection and Research Center (BCRC) in Food Industry Research and Development Institute (Hsinchu, Taiwan). The seed cultures were grown in $2 \mathrm{~L}$ flasks containing $1.3 \mathrm{~L}$ of synthetic medium ( $4.5 \%$ glucose, $0.5 \%$ soybean powder, $0.25 \%$ yeast extract, $0.25 \%$ peptone and $0.05 \% \mathrm{MgSO}_{4}$, 
adjusted to $\mathrm{pH}$ 4.5) Scale-up from a shake flask to $500 \mathrm{~L}$ fermenters and 20 ton fermenters lasted for 5 days and 12 days, respectively. At the end of the fermentation process, the mycelia were then harvested, lyophilized, grounded to a powder and stored in a desiccator at room temperature. Cultivation and liquid fermentation of Lion's mane mushroom (H. erinaceus) mycelium used in this study were conducted, as described previously. The concentration of Erinacine A in mycelium was determined to be $5 \mathrm{mg} / \mathrm{g}$, using the HPLC method described previously [19].

\subsection{Experimental Design}

In the test, three-month-old SAMP8 mice were grouped, with 20 females and 20 males, as follows: control, low dose group (108 $\mathrm{mg} / \mathrm{kg} / \mathrm{bw} /$ day), intermediate dose group ( $215 \mathrm{mg} / \mathrm{kg} / \mathrm{bw} /$ day), high dose group (431 mg/kg/bw/day) EAHEM daily for 13 weeks.

\subsection{Behavioral Tests}

\subsubsection{Passive Avoidance Task}

Single-trial passive avoidance test was conducted in a $35(\mathrm{~W})$ by $17(\mathrm{D})$ by $20(\mathrm{H})$ aluminum shuttle cage (Coulbourn instruments Model E10-15), divided into illuminated and dark compartments and mutually accessible via a $7.5(\mathrm{~W})$ by $6.5(\mathrm{D})$ guillotine door (Coulbourn instruments Model E10-15GD). The bottom of the chamber was lined with parallel metal rods $1 \mathrm{~cm}$ apart, coupled to an electric emitter to administer foot shock. At the start of the test, mice were placed in the illuminated chamber, after allowing $10 \mathrm{~s}$ of environment familiarization, the door to the dark chamber was opened to allow the mouse to freely explore. The dark chamber was naturally favorable to the nocturnal mice. Once the mice entered the dark chamber, the door was quickly closed and a $0.5 \mu \mathrm{A} 0.5 \mathrm{~s}$ foot shock was delivered three consecutive times, each $5 \mathrm{~s}$ apart, thus completing the training session. The memory of the mice was assessed 1 day, 2 days and 3 days after this training step by conducting the same procedure, albeit without delivering any foot shock. The latency time was recorded with total assessment time not exceeding $180 \mathrm{~s}$. Increased latency time indicates better memory in the mice.

\subsubsection{Active Shuttle Avoidance Test}

The same shuttle cage was used to set up an active shuttle avoidance test. In this test, mice were placed in one chamber for an inter-trial interval of $10 \mathrm{~s}$. Subsequently, a light and sound conditioned stimulus (CS) was presented for $10 \mathrm{~s}$. If during CS presentation, the mice still stayed in the same chamber, a $5 \mathrm{~s} 0.3 \mathrm{~mA}$ foot shock was delivered automatically, which serves as the unconditioned stimulus (UCS). If the mice entered the adjacent chamber under CS presentation, foot shock was not delivered. The software presented CS or UCS according to the mice' reaction. Each mouse underwent one session consisting of 5 turns of CS/UCS assessment before being put back into its cage. After 15-20 min of down time, the above CS/UCS session was repeated 4 times each day. This was done for 4 consecutive days. Ultimately, the number of avoidance responses to CS were counted, with fewer avoidance responses indicating relatively weaker memory. The above tests were used to assess the effect of different doses of EAHEM on the learning and memory of mice.

\subsection{Tissue Preparation}

After mice were sacrificed, the brain was removed and fixed in 10\% neutral formaldehyde solution for approximately one week. The method for slicing midbrain tissue was adapted from Shimada et al.'s method [20]. The brain was divided into 6 sectors. The $\beta$-amyloid aggregation area ratio was measured. Computer image processing system Leica Q500 (Ernst Leitz Wetzlar, Wetzlar, Germany) was used to calculate under 20× magnification. The formula was described as: ( $\beta$-amyloid aggregation area/whole brain area) $\times 100 \%$. 


\subsection{Measurement of $i N O S$ and TBARS}

Mice were sacrificed by decapitation, and the brain tissue was extracted according to the method by Glowinski and divided into the cortex and hippocampus [21]. The hippocampus was homogenized after the addition of $1 \mathrm{~mL}$ phosphate buffered saline (PBS), $\mathrm{pH} 7.4$ buffer, then centrifuged at $15,000 \times g$ for $30 \mathrm{~min}$ at $4{ }^{\circ} \mathrm{C}$. The supernatant was kept as a liquid and preserved at $-80{ }^{\circ} \mathrm{C}$ until needed, then it was thawed and centrifuged $\left(12,000 \times \mathrm{g}, 5 \mathrm{~min}, 4^{\circ} \mathrm{C}\right)$. This was collected for the measurement of iNOS by using ELISA kits purchased from USCN (USCN Business Co., Ltd., Wuhan, China). For analysis of the levels of thiobarbituric acid reactive substances (TBARS) in mouse brain, $100 \mu \mathrm{L}$ of homogenized brain supernatant was mixed with $100 \mu \mathrm{L}$ sodium dodecyl sulfate (SDS) solution and $4 \mathrm{mr}$ regent for an hour. The mixture was centrifuged at $1600 \times \mathrm{g}$ under $4{ }^{\circ} \mathrm{C}$ for $10 \mathrm{~min}$, then read the value at $535 \mathrm{~nm}$.

\subsection{Data Analysis}

The data in this study were analyzed by SigmaPlot 10.0 data analysis package. The data are all expressed as mean \pm SEM. The data were analyzed by one-way analysis of variance (ANOVA), to determine the difference between groups. Duncan's multiple range test was used to compare differences between groups. $p<0.05$ is considered significantly different.

\section{Results}

\subsection{Behavioral Assays}

The experiment design for this study is presented in Figure 1. Briefly, male and female SAMP8 mice were fed different doses daily. After 12 weeks of feeding, the latency time in the single-trial passive avoidance test was recorded. The results indicated that in both male and female SAMP8 mice, there was no significant difference between control and treated groups in acquisition training. However, 1 and 2 days after training, latency time was recorded to be significantly higher $(p<0.05)$ in treated groups. During this time, daily EAHEM feeding was not ceased. Latency time displayed a decreasing trend in all groups 3 days after training. This may be due to the absence of foot shock in the tests following the first day of the experiment. The latency time lasted longer 1 and 2 days after training, but due to the decrease in memory retention with elapsed time, latency time consequently decreased. The single-trial passive avoidance test results indicated that feeding EAHEM enhanced the learning and memory of mice (Table 1).

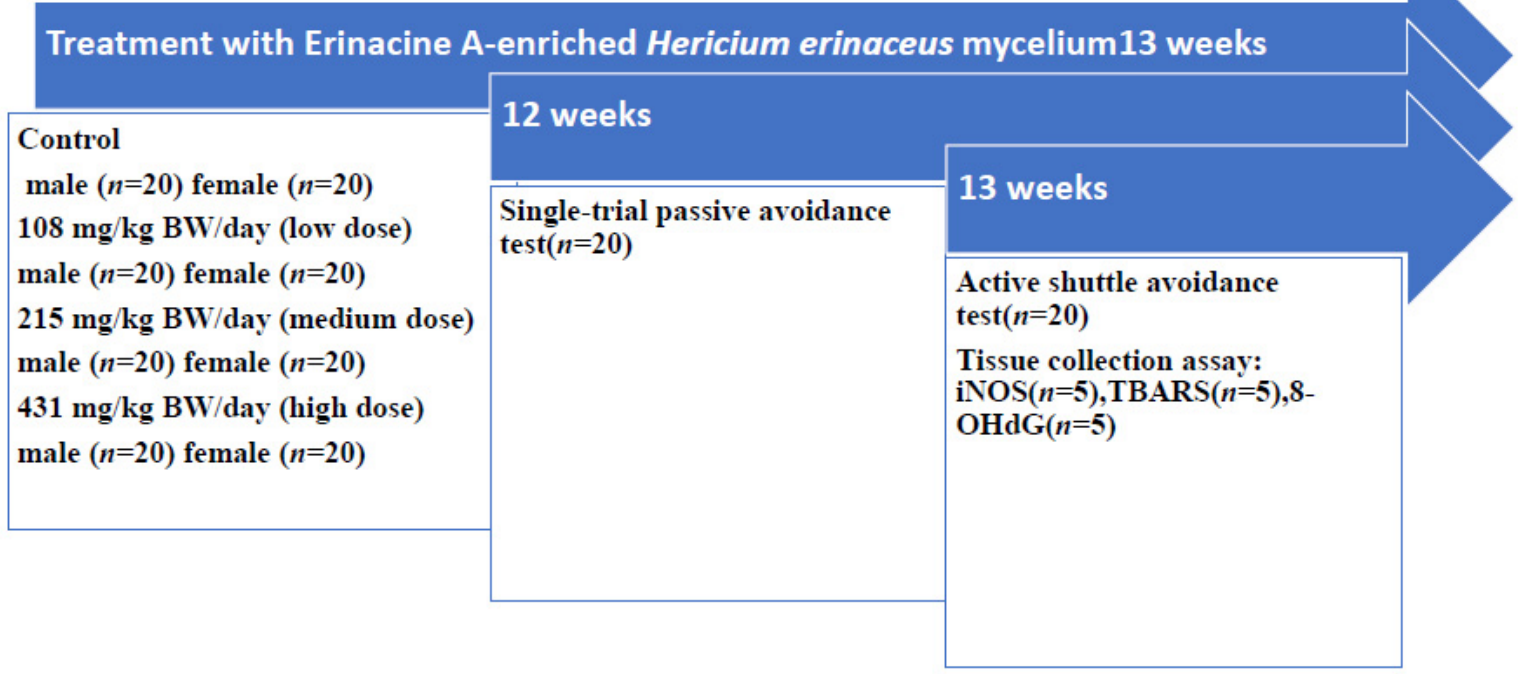

Figure 1. Schematic representation of the experimental design. 
Table 1. Single-trial passive avoidance latency time in mice after 12 weeks feeding.

\begin{tabular}{ccccc}
\hline & Trial & 1 Day & 2 Days & 3 Days \\
\hline Male & & & & \\
Control & $48.20 \pm 0.95$ & $58.55 \pm 1.18^{\mathrm{a}}$ & $56.35 \pm 1.22^{\mathrm{a}}$ & $49.25 \pm 0.86$ \\
$108 \mathrm{mg} / \mathrm{kgBW} /$ day & $49.65 \pm 0.94$ & $67.98 \pm 0.80^{\mathrm{b}}$ & $61.00 \pm 0.79^{\mathrm{b}}$ & $51.50 \pm 0.82$ \\
$215 \mathrm{mg} / \mathrm{kgBW} /$ day & $47.20 \pm 0.86$ & $69.70 \pm 1.11^{\mathrm{b}}$ & $62.20 \pm 0.83^{\mathrm{b}}$ & $51.25 \pm 1.34$ \\
$431 \mathrm{mg} / \mathrm{kgBW} /$ day & $47.40 \pm 0.91$ & $70.80 \pm 0.87^{\mathrm{b}}$ & $63.35 \pm 0.85^{\mathrm{b}}$ & $52.60 \pm 1.56$ \\
Female & & & & \\
Control & $47.60 \pm 1.18$ & $60.65 \pm 0.86^{\mathrm{a}}$ & $55.80 \pm 1.18^{\mathrm{a}}$ & $49.10 \pm 1.01$ \\
$108 \mathrm{mg} / \mathrm{kgBW} /$ day & $48.55 \pm 1.42$ & $70.00 \pm 0.78^{\mathrm{b}}$ & $64.40 \pm 1.15^{\mathrm{b}}$ & $51.85 \pm 1.11$ \\
$215 \mathrm{mg} / \mathrm{kgBW} /$ day & $44.35 \pm 1.46$ & $71.90 \pm 0.82^{\mathrm{b}}$ & $65.85 \pm 0.67^{\mathrm{b}}$ & $52.65 \pm 2.07$ \\
$431 \mathrm{mg} / \mathrm{kgBW} /$ day & $46.30 \pm 1.57$ & $72.20 \pm 0.79^{\mathrm{b}}$ & $64.85 \pm 0.67^{\mathrm{b}}$ & $48.45 \pm 1.86$
\end{tabular}

Values are expressed as mean \pm S.E.M. and analyzed by one-way ANOVA $(n=20)$. Groups with different letters denote significant difference between each group $(p<0.05)$.

Active shuttle avoidance test of SAMP8 mice was conducted after 13 weeks of EAHEM feeding. The average number of avoidance responses recorded during the test was positively correlated to learning. On the first day of the trial, as the mice were still in the training phase, there was no significant difference between avoidance responses of each group. On the 2nd, 3rd and 4th day of the trial, EAHEM-fed groups of male and female mice recorded a significantly higher number of avoidance responses $(p<0.05)$ compared to the control group (Table 2). This indicates that while 12 weeks of feeding with EAHEM did not improve the performance of the mice on the day of training, they were able to retain this training memory afterwards. The results from the two sets of learning memory trials indicate that EAHEM-fed test groups displayed significantly improved learning and memory.

Table 2. Active shuttle avoidance test in mice after 12 weeks feeding.

\begin{tabular}{|c|c|c|c|c|}
\hline & Day 1 & Day 2 & Day 3 & Day 4 \\
\hline \multicolumn{5}{|l|}{ Male } \\
\hline Control & $9.85 \pm 0.34$ & $12.25 \pm 0.36^{\mathrm{a}}$ & $11.55 \pm 0.36^{\mathrm{a}}$ & $12.75 \pm 0.31^{\mathrm{a}}$ \\
\hline $108 \mathrm{mg} / \mathrm{kgBW} /$ day & $10.35 \pm 0.44$ & $14.50 \pm 0.51^{b}$ & $13.85 \pm 0.51^{b}$ & $14.30 \pm 0.56^{b}$ \\
\hline $215 \mathrm{mg} / \mathrm{kgBW} /$ day & $10.00 \pm 0.43$ & $14.90 \pm 0.45^{b}$ & $14.70 \pm 0.45^{b}$ & $15.05 \pm 0.39^{b}$ \\
\hline $431 \mathrm{mg} / \mathrm{kgBW} /$ day & $9.95 \pm 0.32$ & $14.05 \pm 0.40^{b}$ & $14.70 \pm 0.40^{b}$ & $15.00 \pm 0.24^{b}$ \\
\hline \multicolumn{5}{|l|}{ Female } \\
\hline Control & $12.35 \pm 0.57$ & $11.05 \pm 0.40^{\mathrm{a}}$ & $12.30 \pm 0.25^{\mathrm{a}}$ & $13.70 \pm 0.19^{a}$ \\
\hline $108 \mathrm{mg} / \mathrm{kgBW} /$ day & $10.70 \pm 0.44$ & $12.85 \pm 0.37^{b}$ & $14.55 \pm 0.37^{b}$ & $15.35 \pm 0.46^{b}$ \\
\hline $215 \mathrm{mg} / \mathrm{kgBW} /$ day & $10.45 \pm 0.32$ & $13.85 \pm 0.31^{b}$ & $15.55 \pm 0.46^{b}$ & $15.40 \pm 0.20^{b}$ \\
\hline $431 \mathrm{mg} / \mathrm{kgBW} /$ day & $10.20 \pm 0.19$ & $13.50 \pm 0.53^{b}$ & $15.10 \pm 0.37^{b}$ & $15.35 \pm 0.34^{b}$ \\
\hline
\end{tabular}

Values are expressed as mean \pm S.E.M. and analyzed by one-way ANOVA $(n=20)$. Groups with different letters denote significant difference between each group $(p<0.05)$.

\subsection{Comparison of Brain Pathological Markers}

Male and female mice fed with EAHEM possessed significantly lowered brain TBARS levels $(p<0.05)$, with a high dose being the most effective. This shows that after 13 weeks of EAHEM feeding, the brain TBARS levels can be lowered (Figure 2). Male mice fed with a high dose of EAHEM possessed approximately 1.21-fold lower cortical iNOS when compared with control group $(p<0.05)$. At the same time, iNOS activity in the hippocampus was approximately 1.43-fold lower in mice fed with a medium and high dose of EAHEM (Figure 3) compared with the control group. 


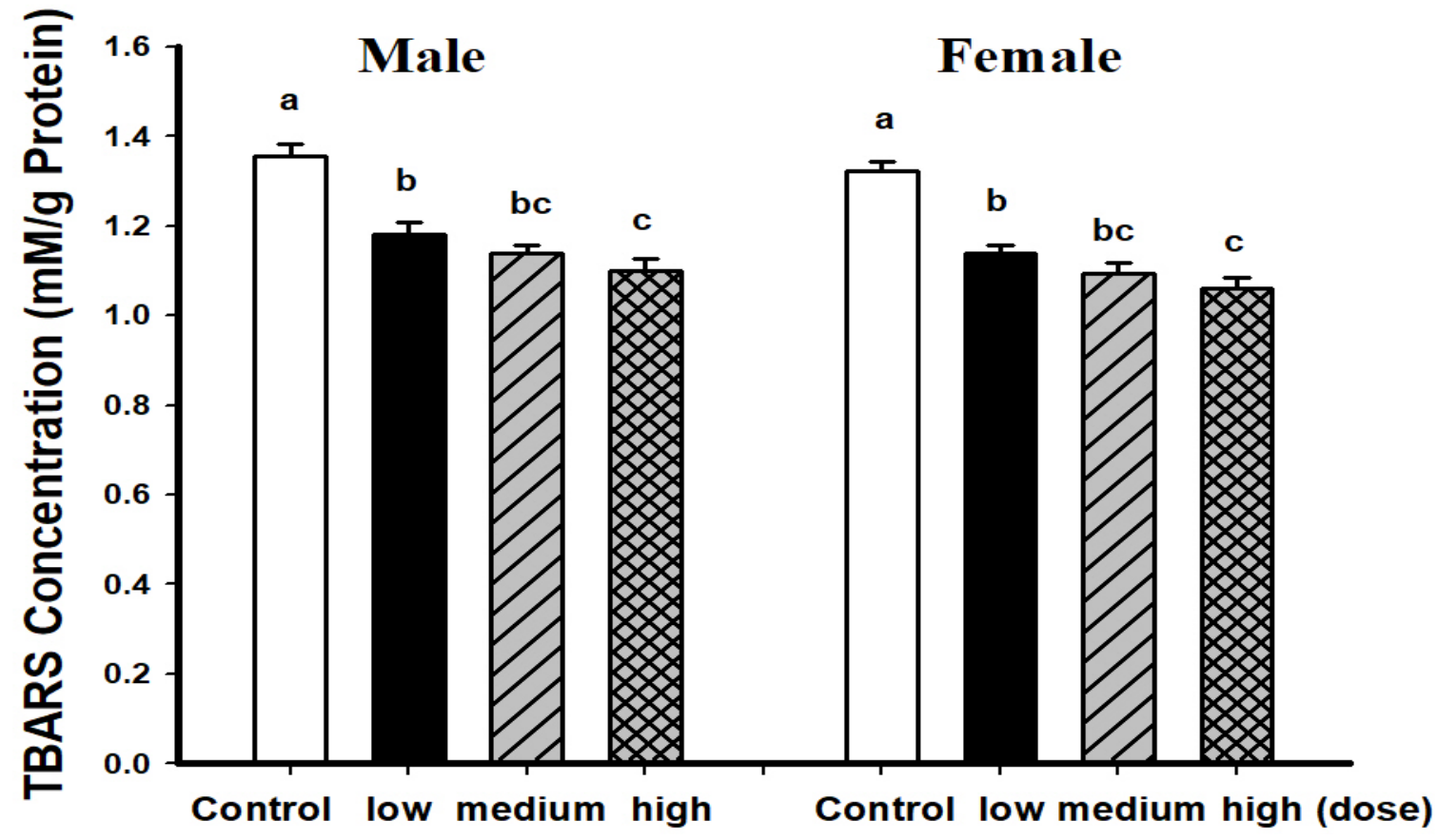

Figure 2. Thiobarbituric acid reactive substances (TBARS) levels in mice brain after 13 weeks feeding. Low dose group (108 mg/kg/bw/day), intermediate dose group ( $215 \mathrm{mg} / \mathrm{kg} / \mathrm{bw} /$ day), high dose group (431 mg/kg/bw/day). Values are expressed as mean \pm S.E.M. and analyzed by one-way ANOVA $(n=10)$. Groups with different letters denote significant difference between each group $(p<0.05)$.

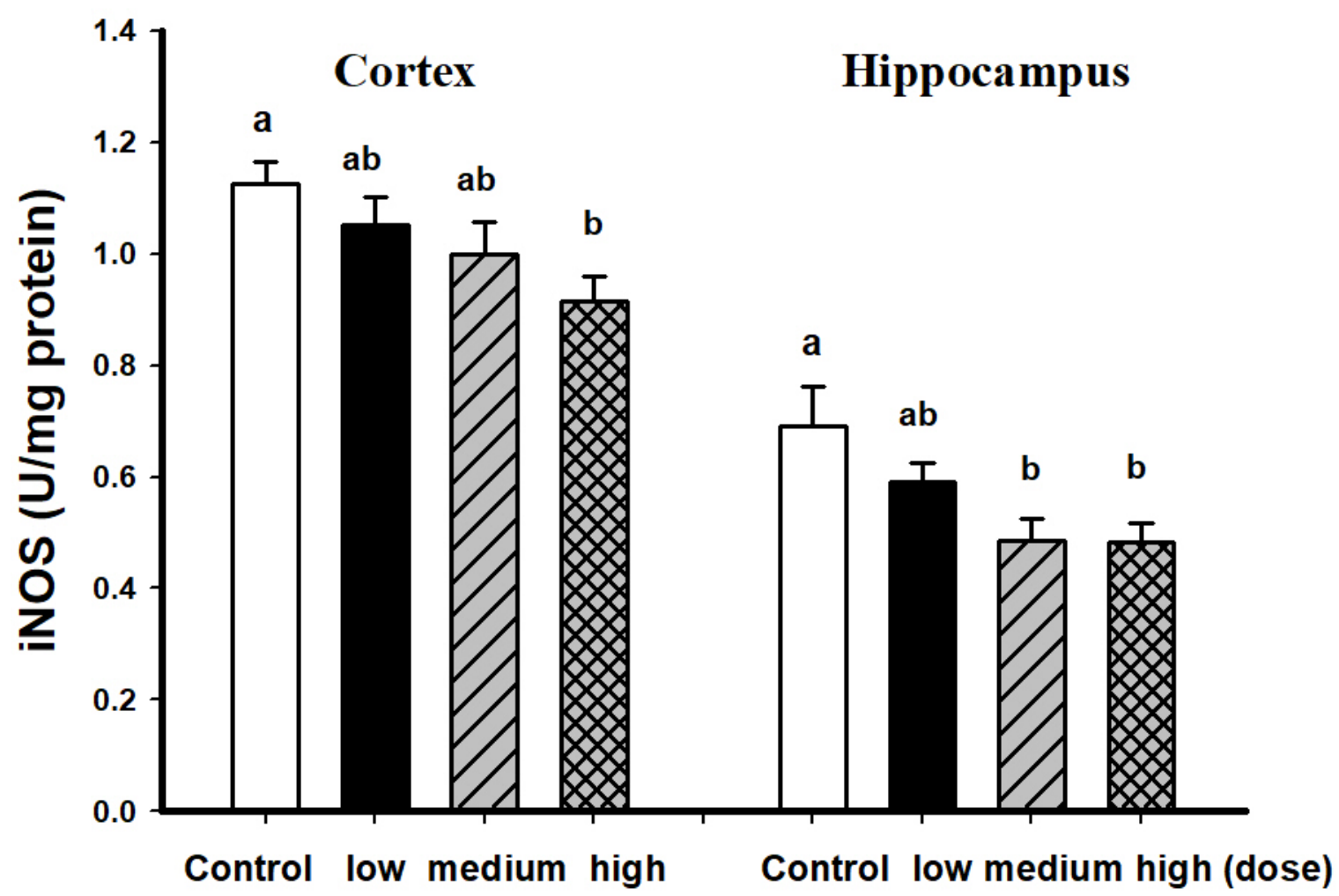

Figure 3. iNOS activity in male mice brain after 13 weeks feeding. Low dose group $(108 \mathrm{mg} / \mathrm{kg} / \mathrm{bw} /$ day $)$, intermediate dose group ( $215 \mathrm{mg} / \mathrm{kg} / \mathrm{bw} /$ day), high dose group (431 mg/kg/bw/day). Values are expressed as mean \pm S.E.M. and analyzed by one-way ANOVA $(n=5)$. Groups with different letters denote significant difference between each group $(p<0.05)$. 
In female SAMP8 mice fed with EAHEM for 13 weeks, the cortical iNOS levels were found to be significantly lower than the control group, up to 1.93-fold decrease when comparing the high dose and control group, while the hippocampus iNOS levels were 1.44-fold lower (Figure 4).

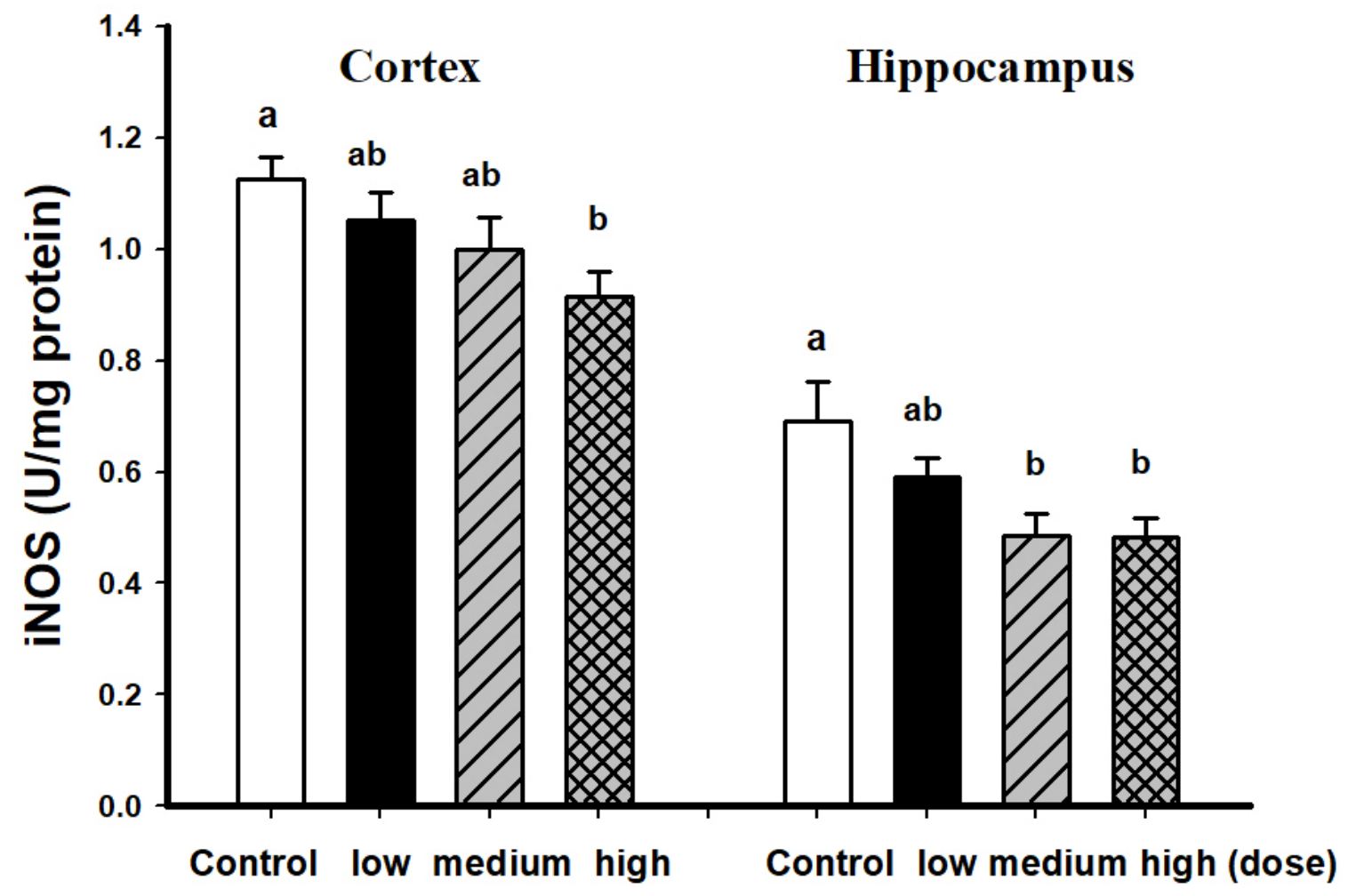

Figure 4. iNOS activity in female mice brain fed after 13 weeks feeding. Low dose group (108 mg/ $\mathrm{kg} / \mathrm{bw} /$ day $)$, intermediate dose group ( $215 \mathrm{mg} / \mathrm{kg} / \mathrm{bw} /$ day), high dose group (431 mg/kg/bw/day). Values are expressed as mean \pm S.E.M. and analyzed by one-way ANOVA $(n=5)$. Groups with different letters denote significant difference between each group $(p<0.05)$.

The histological section of control and EAHEM-fed group were observed under light microscope at $20 \times$ magnification to evaluate alpha amyloid aggregation (Figures 5 and 6). The tissue slice size was $20 \times 50 \mathrm{~mm}$ in length and width, and the appropriate thickness was $5 \mathrm{~mm}$.

Medium and high dose EAHEM-fed mice showed a significantly lower percentage in the brain $\mathrm{A} \beta$ plaque number $(p<0.05)$, by $21.1 \%$ and $24 \%$, respectively. Low, medium and high dose EAHEM-fed mice showed a lower percentage of $\mathrm{A} \beta$ aggregation area $(p<0.05)$ by $12.7 \%, 15.9 \%$ and $19.0 \%$, respectively (Figure 7). 8-hydroxy-2'-deoxyguanosine (8-OHdG) is an indicator of mitochondrial DNA damage [22]. Therefore, we chose to measure 8-OHdG levels in mice brain and found them to be significantly lower in EAHEMfed groups $(p<0.05)$. The high dose group showed the greatest negative difference in 8 -OHdG levels at $83.5 \%$ and $83.7 \%$, compared to that of control, in male and female mice, respectively (Figure 8 ). 


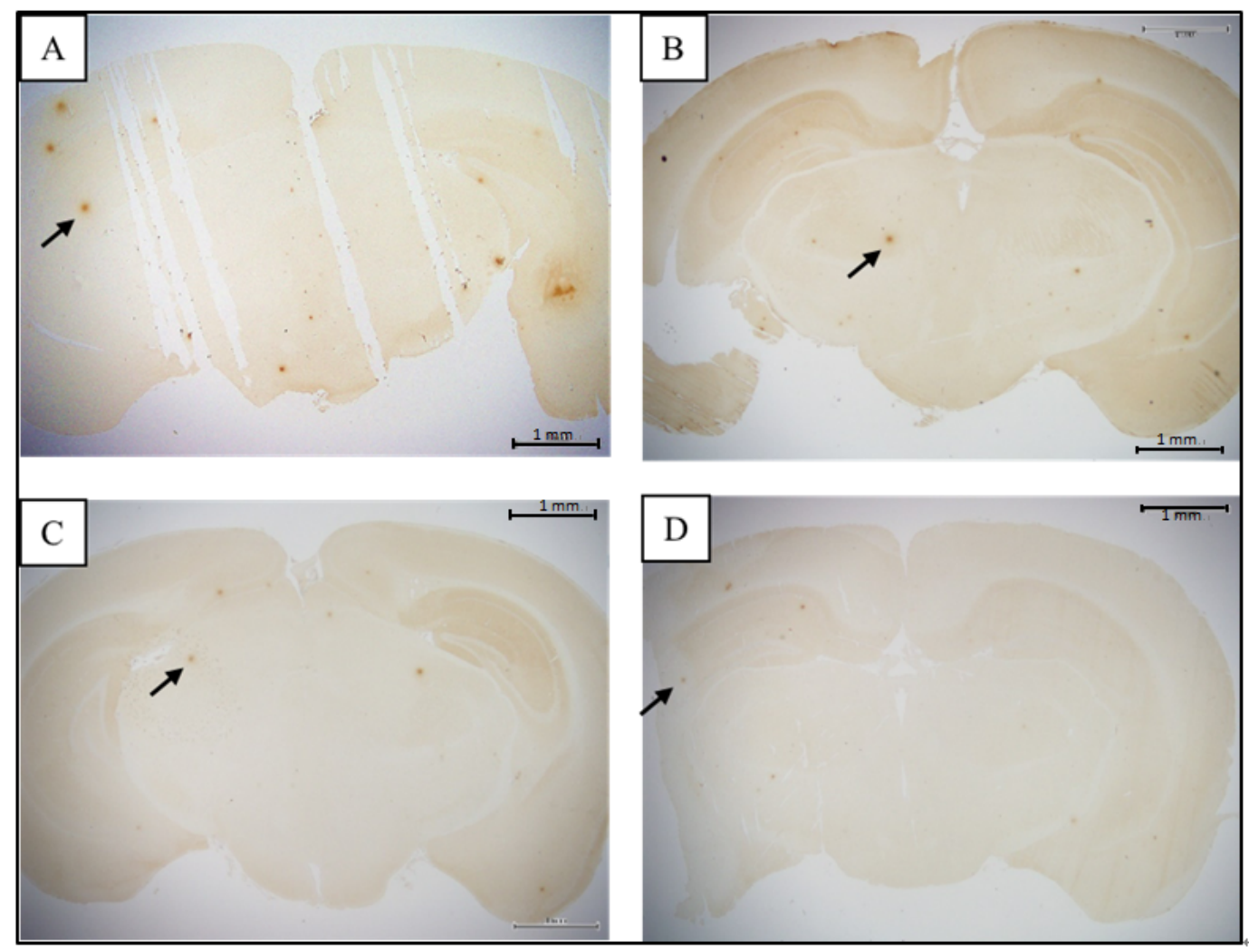

Figure 5. $\beta$-amyloid plaque in male mice $\left(20 \times\right.$ magnification). $(\mathbf{A})=$ control $\left(\mathrm{ddH}_{2} \mathrm{O}\right),(\mathbf{B})=$ low dose $(108 \mathrm{mg} / \mathrm{kg} \mathrm{BW} / \mathrm{day})$, $(\mathbf{C})=$ medium dose $(215 \mathrm{mg} / \mathrm{kg}$ BW/day $),(\mathbf{D})=$ high dose $(431 \mathrm{mg} / \mathrm{kg}$ BW/day $)(n=5)$. Arrows indicate $\beta$-amyloid plaque.
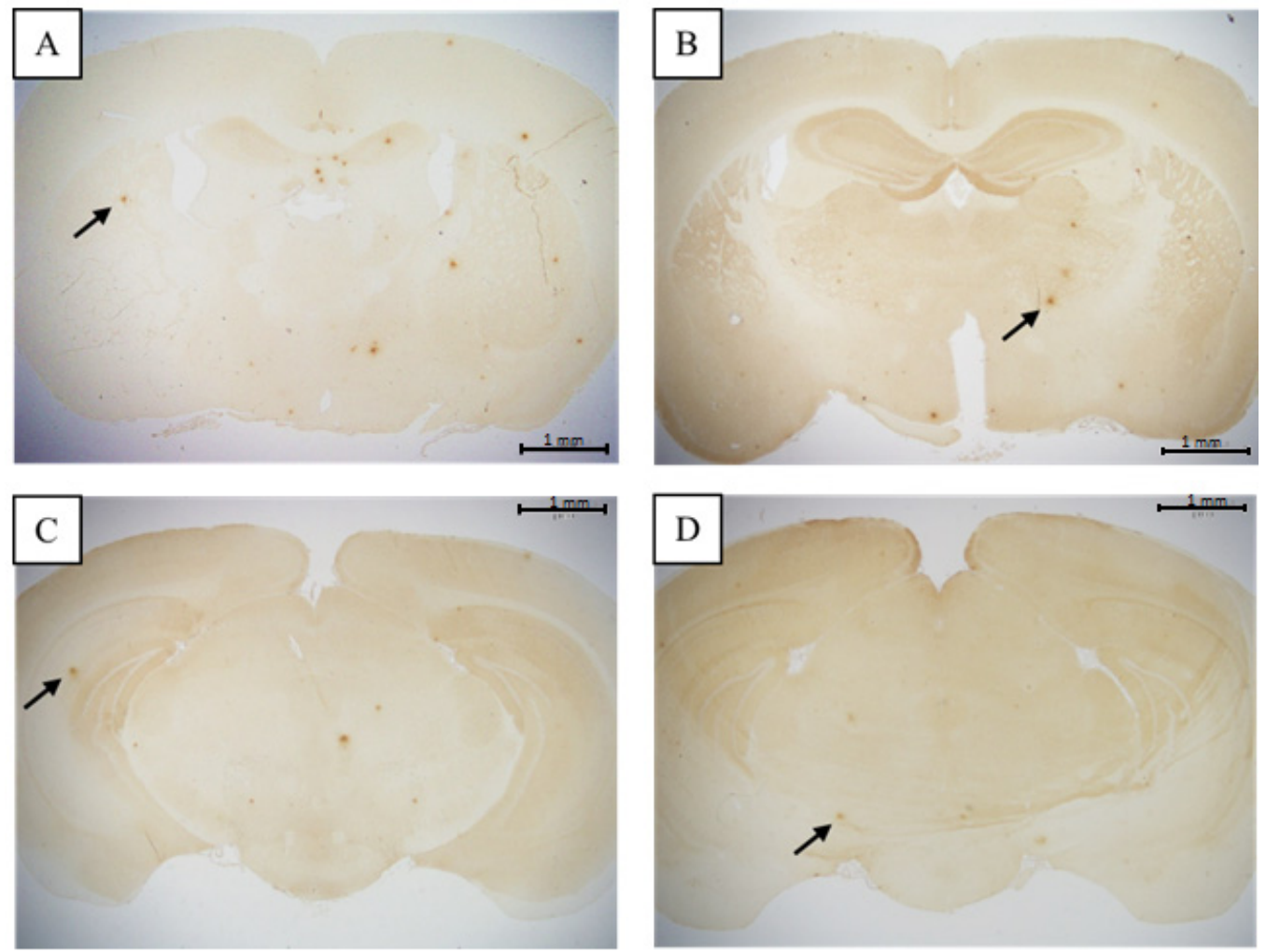

Figure 6. $\beta$-amyloid plaque in female mice $\left(20 \times\right.$ magnification). $(\mathbf{A})=$ control $\left(\mathrm{ddH}_{2} \mathrm{O}\right),(\mathbf{B})=\operatorname{low}$ dose $(108 \mathrm{mg} / \mathrm{kg} \mathrm{BW} / \mathrm{day})$, $(\mathbf{C})=$ medium dose $(215 \mathrm{mg} / \mathrm{kg} \mathrm{BW} /$ day $),(\mathbf{D})=$ high dose $(431 \mathrm{mg} / \mathrm{kg} \mathrm{BW} /$ day $)(n=5)$. Arrows indicate $\beta$-amyloid plaque 
Nutrients 2021, 13, 3659

9 of 13

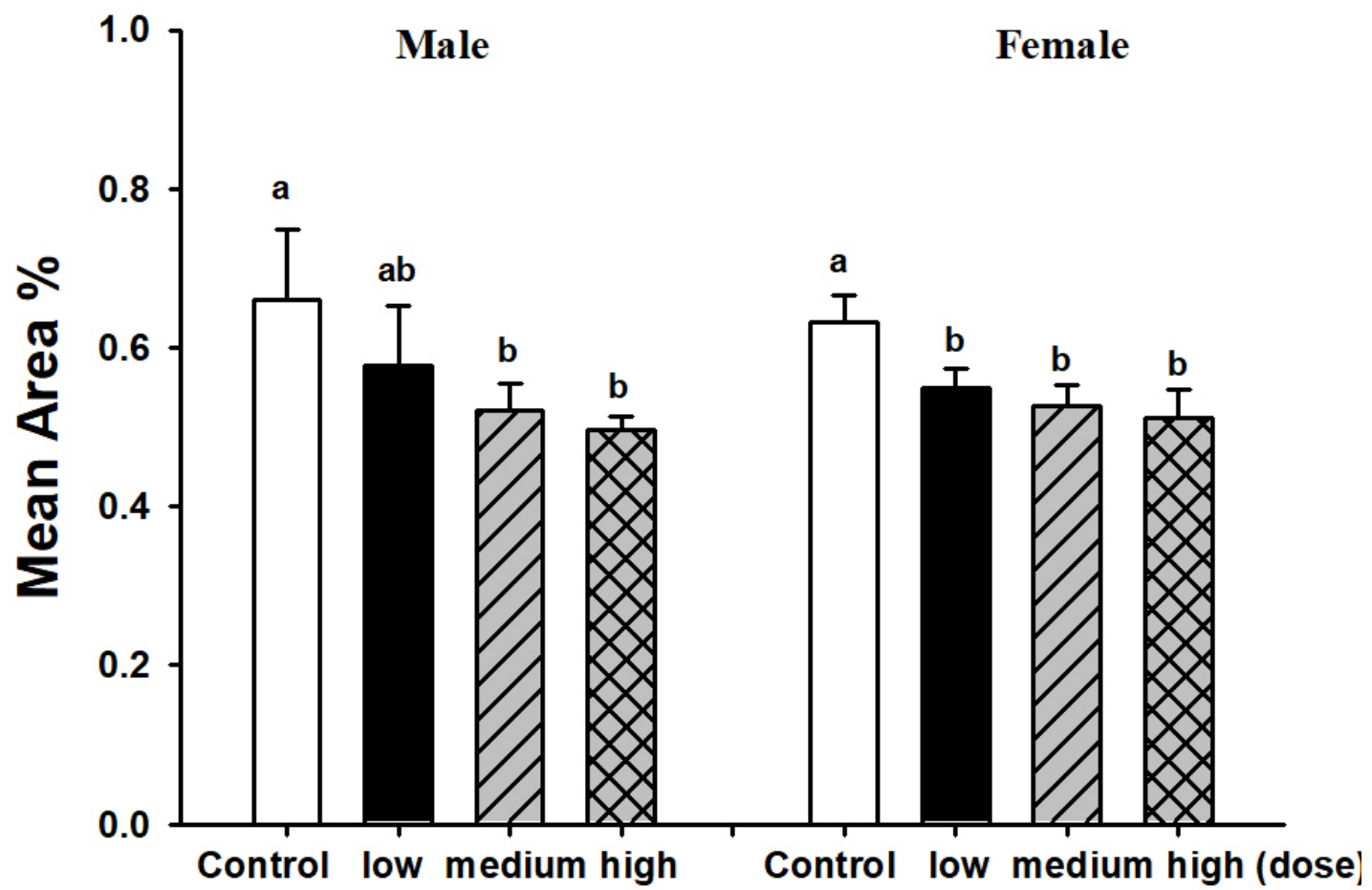

Figure 7. Mean area of $\beta$-amyloid plaque in male mice brain after 13 weeks feeding. Low dose group (108 mg/kg/bw/day), intermediate dose group (215 mg/kg/bw/day), high dose group (431 mg/kg/bw/day). Values are expressed as mean \pm S.E.M. and analyzed by one-way ANOVA $(n=5)$. Groups with different letters denote significant difference between each group $(p<0.05)$.

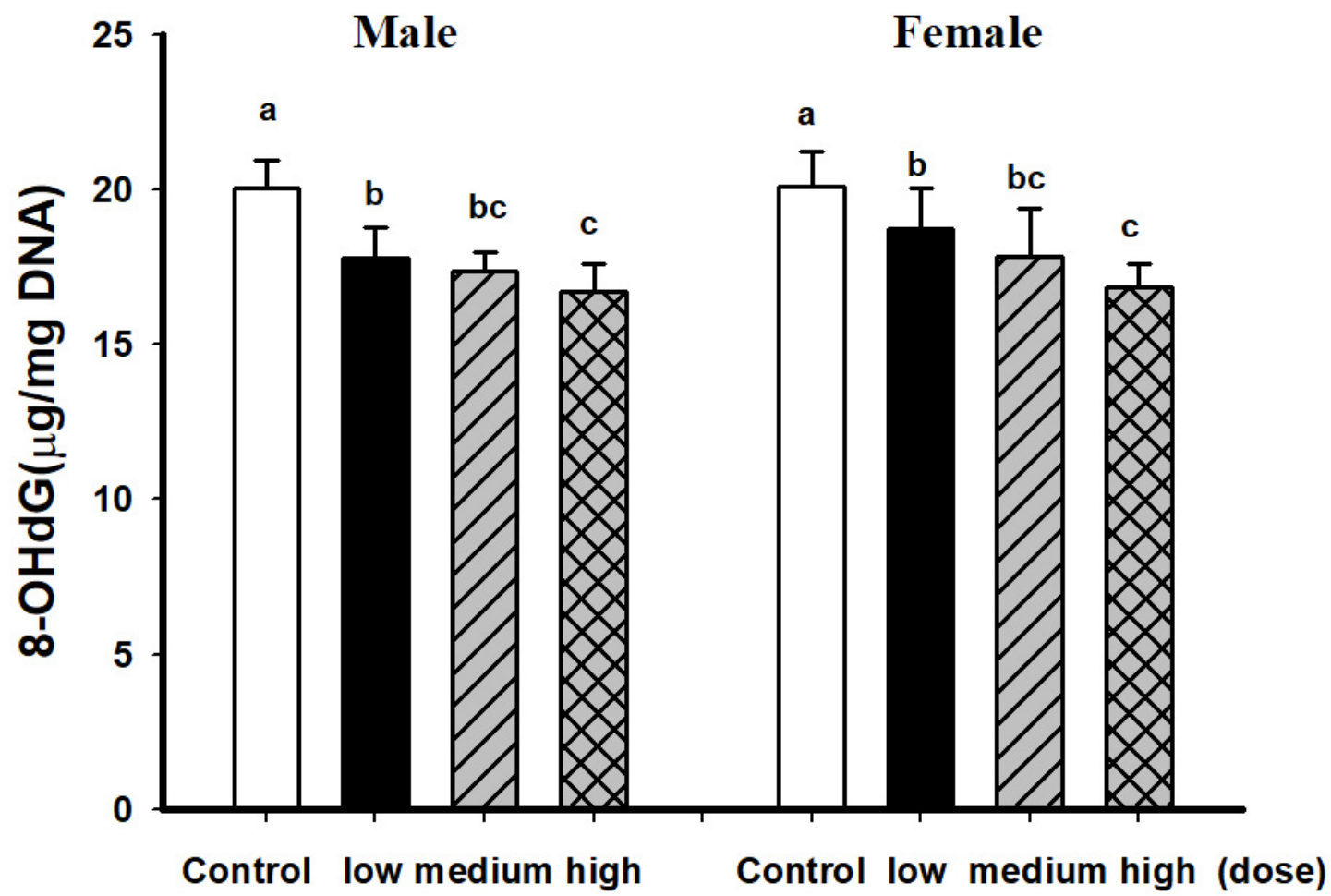

Figure 8. 8-OHdG levels of mice brain after 13 weeks feeding. Low dose group (108 mg/kg/bw/day), intermediate dose group (215 mg/kg/bw/day), high dose group (431 mg/kg/bw/day). Values are expressed as mean \pm S.E.M. and analyzed by one-way ANOVA $(n=10)$. Groups with different letters denote significant difference between each group $(p<0.05)$. 


\section{Discussion}

Aging is known to be associated with cognitive impediment. The biochemical and physiological basis is still not clear, but the hippocampus is known to play an important role in cognitive function. Kumar et al. utilized an array technique to probe how hippocampus genes affect cognitive impairment in SAMP8 mice of different ages, finding significant differences in anti-oxidative and xenobiotic metabolism gene expression [23]. SAMP8 mice displayed learning and memory deficits as young as 4 months of age, as well as further time-dependent decline [24]. The results of the active avoidance and passive avoidance test in this study demonstrate that long-term intake of EAHEM can improve learning as well as memory retention. Previously, a similar recovery of cognitive decline in APP/PS1 transgenic mice conferred by erinacine A was demonstrated by Tzeng et al. using a Morris water maze, wherein mice fed with erinacine A displayed shorter escape latency [25].

Brain neurons and endothelial cells produce nitric oxide (NO) as a product of Larginine and oxygen by nitric oxide synthase, which act as signaling molecules in the brain. There are three isoforms of nitric oxide synthase, endothelial NO synthase (eNOS), neuronal NO synthase (nNOS) and inducible NO enzyme (iNOS). In most cells such as glial cells, macrophages, skeletal muscle, neurons, platelets and white blood cells, iNOS expression is elevated in response to inflammation and oxidative pressure [26]. In this study, feeding EAHEM to mice lowered iNOS expression in the brain, implying that its protective effect is conferred by directly lowering oxidative stress or inflammation. This is in agreement with Lee et al.'s study, wherein the feeding of H. erinaceus mycelium or erinacine A correlated with the attenuation of p38/MAPK and C/EBP homologous protein (CHOP), downregulation of iNOS and nitrotyrosine-containing proteins, resulting in reduction of inflammation, increased free radical scavenging and protection from ischemic brain damage [16].

More and more evidence points toward the long-term accumulation of peroxidation of DNA, proteins and lipids by free radicals as the culprit of the aging brain and functional degeneration [27]. Four age-related diseases have been pathologically linked to free radical reactions, including cancer, atherosclerosis, hypertension and amyloidosis. Regular consumption of foods that inhibit free radical reactions, such as dietary fibers can decrease endogenous free radical reactions, consequently lengthening the patient's life span by five or more years as well as leading to a healthier life [28]. In our study, TBARS levels in the brain were indeed measured to be decreased, indicating decreased lipid peroxidation. Previous studies on 13 AD patients compared to 10 control subjects found that TBARS levels were higher for AD patients in all parts of the brain, except the middle frontal gyrus [29]. Free radicals have also been shown to cause damage to brain lipids, carbohydrates, proteins and DNA, which is highly correlated to neuronal death in neurodegenerative diseases. Peroxidation of lipids in the brain causes poly-unsaturated fatty acid (PUFA) levels to drop, and 4-hydroxynonenal (4-HNE), a neurotoxic aldehyde product of PUFA oxidation, to rise [30].

The anti-oxidative stress capacity of EAHEM has also been reported previously in an MPTP-induced model of the increase in oxidative stress and consequent dopaminergic neuronal cell death. Feeding EAHEM was found to lower nitrotyrosine and 4-HNE expression while also recovering motor ability in a mouse rotarod test. The mechanism is that erinacine A treatment provides protection against the endoplasmic reticulum stress caused by neurotoxicity and neuronal cell apoptosis mainly via activating RE1 $\alpha /$ TRAF2, JNK1/2 and p38 MAPK pathways, thus allowing expression of CHOP, IKB- $\beta$ and NF- $\mathrm{KB}$, as well as Fas and Bax [31]. Shimbo et al. observed that the feeding of erinacine $\mathrm{A}$ at $8 \mathrm{mg} / \mathrm{kg} /$ day to rats increased catecholamine and NGF [15].

$\mathrm{AD}$ is a chronic neurodegenerative disease that primarily affects the medial temporal lobe and the neocortical structures. The pathological markers of AD include neuronal plaques and neuronal entanglement, the former of which is caused by amyloid- $\beta$ peptide aggregation and the latter caused by hyperphosphorylation of microtubular tau protein in neurons that leads to changes in the cellular structure [32]. A $\beta$, as oligomers, are neurotoxic, 
causing damage to cellular signal transduction, including impaired synaptic plasticity, increased tau protein phosphorylation, increased GSK-3 $\beta$ activity, imbalance of calcium homeostasis causing neuronal cell death and apoptosis. $A \beta$ also interacts with neurons and neuroglial cells, activating inflammation, mitochondrial dysfunction and increasing oxidative pressure $[33,34]$. Currently, two types of proteins have been identified as being closely linked to the removal of $A \beta$ in the brain: apolipoprotein $E$ (ApoE) and insulindegrading enzyme (IDE). Although the mechanism of action is not currently confirmed, ApoE has been reported to interact with $\mathrm{A} \beta$ to inhibit its polymerization or chaperone its proteolysis, while IDE has been shown to degrade soluble A $\beta$ extracellularly [35-37]. Previous studies indicated that feeding EAHEM to APP/PS1 mice showed increased IDE expression and decreased glial and microglial cell activation, both of which are possible factors that may lower $A \beta$ plaque burden [18]. A similar downward trend in $A \beta$ plaque percentage is present in our study. Previously, Chien-Chih et al. also proved that erinacine A increased IDE levels to twice that of the control group in APP/PS1 mice [25].

Reactive oxygen species (ROS) are products of many processes, such as arachidonic acid metabolism, lipid peroxidation and phagocyte activation [38]. During ischemiareperfusion in the brain, $8-\mathrm{OHdG}$ is generated from a DNA base modified by ROS [39]. Luceri et al. evaluated serum ROS, 8-OHdG and DNA repair enzyme levels in very young ( 2 months old), young ( 8 months old) and middle aged (15 months old) mice, revealing that a decrease in DNA repair capabilities coincided with elevated 8-OHdG in older mice [40]. 8-OHdG is also related to neurodegenerative diseases, as it is a good diagnostic marker found in the cerebrospinal fluid of Parkinson's disease patients [41]. In a study on major depressive disorder (MDD) and patients' inflammatory and oxidative stress-related responses to an antidepressant drug, those who responded poorly to the drug possessed higher levels of F2-isoprostanes prior to treatment, while 8-OHdG and IL-6 were both associated with antidepressant response [42]. There is some evidence that 8-OHdG immunoreactivity may not be an ideal evaluation method of infarction injury. In Nogami et al.'s study, age was found to be negatively correlated to 8-OHdG immunoreactivity in glial cells of autopsied humans. There was no significant difference in 8-OHdG reactivity between glial cells in the area immediately surrounding the infarction and the non-ischemic areas [43]. In Chiu et al.'s study, ethanolic extract of EAHEM was given to mice before challenged with repeated restraint stress (RS), tail suspension test and forced swimming test to evaluate its impact on depression behavior and serum markers. Serotonin and dopamine levels were found to be significantly elevated, while inflammatory markers IL-6 and TNF- $\alpha$ were both significantly lowered. The mechanism was demonstrated to be the activation of the BDNF/TrkB/PI3K/Akt/GSK-3 pathways to inhibit NF-KB pathway [44]. The literature above strongly supports that EAHEM decreases inflammation and at the same time, prevents oxidative stress to confer anti-aging functions.

\section{Conclusions}

This study demonstrates that EAHEM can lower oxidative stress in the brain and further prevent chronic inflammation, consequently decreasing amyloid aggregation and improving learning and memory. Future efforts will focus on elucidating the mechanism, and possibly achieving the inhibition of amyloid generation, enhancement of amyloid clearance or neuronal regeneration.

Author Contributions: L.-Y.L., data analysis, and participated in the drafted manuscript; W.C., writing-original draft; W.-P.C., participated in ferment of H. erinaceus mycelia; M.-F.W., methodology, project administration, supervision; Y.-J.C., methodology; C.-C.C., project administration, supervision, writing-review and editing; K.-C.T., participated in its design and coordination. All authors have read and agreed to the published version of the manuscript.

Funding: This research received no external funding. 
Institutional Review Board Statement: The study was conducted according to the guidelines of the Institutional Animal Care and Use Committee in Providence University (Taichung City, Taiwan) with the number 20120918-P04.

Informed Consent Statement: Not applicable.

Data Availability Statement: All data can be assessed from L.Y. Lee via the email address.

Acknowledgments: We thank Jiunn-Wang Liao from the Graduate Institute of Veterinary Pathobiology, National Chung Hsing University (Taichung, Taiwan), for helping us with the tissue slicing and pathological examination. We also give a special thanks to Tseng Andrew, Chief Executive Officer, at Grape King Bio Ltd. (Taoyuan, Taiwan) for his permission on providing erinacine A-enriched Hericeum erinaceus mycelium dry powder with mass production as the sample in this experiment.

Conflicts of Interest: The authors declare that there is no conflict of interests.

\section{References}

1. Winslow, B.T.; Onysko, M.K.; Stob, C.M.; Hazlewood, K.A. Treatment of Alzheimer disease. Am. Fam. Physician 2011, 83, 1403-1412.

2. Solomon, A.; Mangialasche, F.; Richard, E.; Andrieu, S.; Bennett, D.A.; Breteler, M.; Fratiglioni, L.; Hooshmand, B.; Khachaturian, A.S.; Schneider, L.S.; et al. Advances in the prevention of Alzheimer's disease and dementia. J. Intern. Med. 2011, 253, 229-250. [CrossRef]

3. Kanasi, E.; Ayilavarapu, S.; Jones, J. The aging population: Demographics and the biology of aging. Periodontol. 2000 2016, 72 , 13-18. [CrossRef] [PubMed]

4. Brunet, A.; Berger, S.L. Epigenetics of aging and aging-related disease. J. Gerontol. A Biol. Sci. Med. Sci. 2014, 6, 17-20. [CrossRef] [PubMed]

5. Cole, J.H.; Marioni, R.E.; Harris, S.E.; Deary, I.J. Brain age and other bodily 'ages': Implications for neuropsychiatry. Mol. Psychiatry 2019, 24, 266-281. [CrossRef]

6. Butterfield, D.A.; Poon, H.F. The senescence-accelerated prone mouse (SAMP8): A model of age-related cognitive decline with relevance to alterations of the gene expression and protein abnormalities in Alzheimer's disease. Exp. Gerontol. 2005, 40, 774-783. [CrossRef] [PubMed]

7. Morley, J.E. The SAMP8 mouse: A model of Alzheimer disease? Biogerontology 2002, 3, 57-60. [CrossRef]

8. Son, C.-G.; Shin, J.-W.; Cho, J.-H.; Cho, C.-K.; Yun, C.-H.; Han, S.-H. Induction of murine interleukin-1 beta expression by water-soluble components from Hericium erinaceum. Acta Pharmacol. Sin. 2006, 27, 1058-1064. [CrossRef]

9. Wang, M.; Gao, Y.; Xu, D.; Gao, Q. A polysaccharide from cultured mycelium of Hericium erinaceus and its anti-chronic atrophic gastritis activity. Int. J. Biol. Macromol. 2015, 81, 656-661. [CrossRef]

10. Yim, M.-H.; Shin, J.-W.; Son, J.-Y.; Oh, S.-M.; Han, S.-H.; Cho, J.-H.; Cho, C.-K.; Yoo, H.-S.; Lee, Y.-W.; Son, C.-G.; et al. Soluble components of Hericium erinaceum induce NK cell activation via production of interleukin-12 in mice splenocytes. Acta Pharmacol. Sin. 2007, 28, 901-907. [CrossRef]

11. Kawagishi, H.; Ando, M.; Sakamoto, H.; Yoshida, S.; Ojima, F.; Ishiguro, Y.; Ukai, N.; Furukawa, S. Hericenones C, D and E, stimulators of nerve growth factor (NGF)-synthesis, from the mushroom Hericium erinaceum. Tetrahedron Lett. 1991, 32, $4561-4564$. [CrossRef]

12. Kawagishi, H.; Shimada, A.; Shirai, R.; Okamoto, K.; Ojima, F.; Sakamoto, H.; Ishiguro, Y.; Furukawa, S. Erinacines A, B and C, strong stimulators of nerve growth factor (NGF)-synthesis, from the mycelia of Hericium erinaceum. Tetrahedron Lett. 1994, 35, 1569-1572. [CrossRef]

13. Kawagishi, H.; Shimada, A.; Hosokawa, S.; Mori, H.; Sakamoto, H.; Ishiguro, Y.; Sakemi, S.; Bordner, J.; Kojima, N.; Furukawa, S. Erinacines E, F, and G, stimulators of nerve growth factor (NGF)-synthesis, from the mycelia of Hericium erinaceum. Tetrahedron Lett. 1996, 37, 7399-7402. [CrossRef]

14. Lee, E.W.; Shizuki, K.; Hosokawa, S.; Suzuki, M.; Suganuma, H.; Inakuma, T.; Li, J.; Ohnishi-Kameyama, M.; Nagata, T.; Furukawa, S.; et al. Two novel diterpenoids, erinacines H and I from the mycelia of Hericium erinaceum. Biosci. Biotechnol. Biochem. 2000, 64, 2402-2405. [CrossRef] [PubMed]

15. Shimbo, M.; Kawagishi, H.; Yokogoshi, H. Erinacine A increases catecholamine and nerve growth factor content in the central nervous system of rats. Nutr. Res. 2005, 25, 617-623. [CrossRef]

16. Lee, K.-F.; Chen, J.-H.; Teng, C.-C.; Shen, C.-H.; Hsieh, M.-C.; Lu, C.-C.; Lee, K.-C.; Lee, L.-Y.; Chen, W.-P.; Chen, C.-C.; et al. Protective effects of Hericium erinaceus mycelium and its isolated erinacine A against ischemia-injury-induced neuronal cell death via the inhibition of iNOS/p38 MAPK and nitrotyrosine. Int. J. Mol. Sci. 2014, 15, 15073-15089. [CrossRef]

17. Kuo, H.-C.; Lu, C.-C.; Shen, C.-H.; Tung, S.-Y.; Hsieh, M.-C.; Lee, K.-C.; Lee, L.-Y.; Chen, C.-C.; Teng, C.-C.; Huang, W.-S.; et al. Hericium erinaceus mycelium and its isolated erinacine A protection from MPTP-induced neurotoxicity through the ER stress, triggering an apoptosis cascade. J. Transl. Med. 2016, 14, 78. [CrossRef] 
18. Tzeng, T.-T.; Chen, C.-C.; Lee, L.-Y.; Chen, W.-P.; Lu, C.-K.; Shen, C.-C.; Huang, F.C.-Y.; Chen, C.-C.; Shiao, Y.-J. Erinacine A-enriched Hericium erinaceus mycelium ameliorates Alzheimer's disease-related pathologies in APPswe/PS1dE9 transgenic mice. J. Biomed. Sci. 2016, 23, 49.

19. Li, I.-C.; Chen, Y.-L.; Lee, L.-Y.; Chen, W.-P.; Tsai, Y.-T.; Chen, C.-C. Evaluation of the toxicological safety of erinacine A-enriched Hericium erinaceus in a 28-day oral feeding study in Sprague-Dawley rats. Food Chem. Toxicol. 2014, 70, 61-67. [CrossRef]

20. Shimada, A.; Hosokawa, M.; Ohta, A.; Akiguchi, I.; Takeda, T. Localization of atrophy-prone areas in the aging mouse brain: Comparison between the brain atrophy model SAM-P/10 and the normal control SAM-R/1. Neuroscience 1994, 59, 859-869. [CrossRef]

21. Glowinski, J.; Iversen, L. Regional studies of catecholamines in the rat brain-III: Subcellullar distribution of endogenous and exogenous catecholamines in various brain regions. Biochem. Pharmacol. 1966, 15, 977-987. [CrossRef]

22. DeBalsi, K.L.; Hoff, K.E.; Copeland, W.C. Role of the mitochondrial DNA replication machinery in mitochondrial DNA mutagenesis, aging and age-related diseases. Ageing Res. Rev. 2017, 33, 89-104. [CrossRef]

23. Kumar, V.B.; Franko, M.W.; Farr, S.A.; Armbrecht, H.J.; Morley, J.E. Identification of age-dependent changes in expression of senescence-accelerated mouse (SAMP8) hippocampal proteins by expression array analysis. Biochem. Biophys. Res. Commun. 2000, 272, 657-661. [CrossRef]

24. Flood, J.F.; Morley, J.E. Learning and memory in the SAMP8 mouse. Neurosci. Biobehav. Rev. 1997, 22, 1-20. [CrossRef]

25. Tzeng, T.-T.; Chen, C.-C.; Chen, C.-C.; Tsay, H.-J.; Lee, L.-Y.; Chen, W.-P.; Shen, C.-C.; Shiao, Y.-J. The cyanthin diterpenoid and sesterterpene constituents of Hericium erinaceus mycelium ameliorate Alzheimer's disease-related pathologies in APP/PS1 transgenic mice. Int. J. Mol. Sci. 2018, 19, 598. [CrossRef]

26. Malinski, T. Nitric oxide and nitroxidative stress in Alzheimer's disease. J. Alzheimers Dis. 2007, 11, 207-218. [CrossRef] [PubMed]

27. Poon, H.F.; Calabrese, V.; Scapagnini, G.; Butterfield, D.A. Free radicals and brain aging. Clin. Geriatr. Med. 2004, 20, 329-359. [CrossRef] [PubMed]

28. Harman, D. Prolongation of life: Role of free radical reactions in aging. J. Am. Geriatr. Soc. 1969, 17, 721-735. [CrossRef] [PubMed]

29. Lovell, M.A.; Ehmann, W.D.; Butler, S.M.; Markesbery, W.R. Elevated thiobarbituric acid-reactive substances and antioxidant enzyme activity in the brain in Alzheimer's disease. Neurology 1995, 45, 1594-1601. [CrossRef] [PubMed]

30. Markesbery, W.R.; Carney, J.M. Oxidative alterations in Alzheimer's disease. Brain Pathol. 1999, 9, 133-146. [CrossRef]

31. De-Paula, V.J.; Radanovic, M.; Diniz, B.S.; Forlenza, O.V. Alzheimer's disease. Subcell. Biochem. 2012, 65, 329-352.

32. Roberts, G.W.; Gentleman, S.M.; Lynch, A.; Murray, L.; Landon, M.; Graham, D.I. Beta amyloid protein deposition in the brain after severe head injury: Implications for the pathogenesis of Alzheimer's disease. J. Neurol. Neurosurg. Psychiatry 1994, 57, 419-425. [CrossRef]

33. Sanz-Blasco, S.; Valero, R.A.; Rodriguez-Crespo, I.; Villalobos, C.; Nunez, L. Mitochondrial Ca ${ }^{2+}$ overload underlies A $\beta$ oligomers neurotoxicity providing an unexpected mechanism of neuroprotection by NSAIDs. PLoS ONE 2008, 3, e2718. [CrossRef]

34. Jiang, Q.; Lee, C.D.; Mandrekar, S.; Wilkinson, B.; Cramer, P.; Zelcer, N.; Mann, K.; Lamb, B.; Willson, T.M.; Collins, J.L. ApoE promotes the proteolytic degradation of A $\beta$. Neuron 2008, 58, 681-693. [CrossRef]

35. Kurochkin, I.V.; Guarnera, E.; Berezovsky, I.N. Insulin-degrading enzyme in the fight against Alzheimer's disease. Trends Pharmacol. Sci. 2018, 39, 49-58. [CrossRef] [PubMed]

36. Recuero, M.; Serrano, E.; Bullido, M.J.; Valdivieso, F. A $\beta$ production as consequence of cellular death of a human neuroblastoma overexpressing APP. FEBS Lett. 2004, 570, 114-118. [CrossRef] [PubMed]

37. Chen, C.-C.; Tzeng, T.-T.; Chen, C.-C.; Ni, C.-L.; Lee, L.-Y.; Chen, W.-P.; Shiao, Y.-J.; Shen, C.-C. Erinacine S, a rare sesterterpene from the mycelia of Hericium erinaceus. J. Nat. Prod. 2016, 79, 438-441. [CrossRef]

38. Ayala, A.; Muñoz, M.F.; Argüelles, S. Lipid peroxidation: Production, metabolism, and signaling mechanisms of malondialdehyde and 4-hydroxy-2-nonenal. Oxid. Med. Cell. Longev. 2014, 2014, 360438. [CrossRef] [PubMed]

39. Won, M.H.; Kang, T.-C.; Jeon, G.-S.; Lee, J.-C.; Kim, D.-Y.; Choi, E.-M.; Lee, K.H.; Choi, C.D.; Chung, M.-H.; Cho, S.S. Immunohistochemical detection of oxidative DNA damage induced by ischemia-reperfusion insults in gerbil hippocampus in vivo. Brain Res. 1999, 836, 70-78. [CrossRef]

40. Luceri, C.; Bigagli, E.; Femia, A.P.; Caderni, G.; Giovannelli, L.; Lodovici, M. Aging related changes in circulating reactive oxygen species (ROS) and protein carbonyls are indicative of liver oxidative injury. Toxicol. Rep. 2018, 5, 141-145. [CrossRef] [PubMed]

41. Gmitterová, K.; Heinemann, U.; Gawinecka, J.; Varges, D.; Ciesielczyk, B.; Valkovic, P.; Benetin, J.; Zerr, I. 8-OHdG in cerebrospinal fluid as a marker of oxidative stress in various neurodegenerative diseases. Neurodegener. Dis. 2009, 6, 263-269. [CrossRef] [PubMed]

42. Lindqvist, D.; Dhabhar, F.S.; James, S.J.; Hough, C.M.; Jain, F.A.; Bersani, F.S.; Reus, V.; Verhoeven, J.E.; Epel, E.S.; Mahan, L.; et al. Oxidative stress, inflammation and treatment response in major depression. Psychoneuroendocrinology 2017, 76, 197-205. [CrossRef] [PubMed]

43. Nogami, M.; Shiga, J.; Inuzuka, N.; Takatsu, A. Age-associated decrease in 8-hydroxy-2'-deoxyguanosine (8-OHdG) immunoreactivity in the autopsied brain. Leg. Med. 2002, 1, 29-33. [CrossRef]

44. Chiu, C.H.; Chyau, C.C.; Chen, C.C.; Lee, L.Y.; Chen, W.P.; Liu, J.L.; Lin, W.H.; Mong, M.C. Erinacine A-enriched Hericium erinaceus mycelium produces antidepressant-like effects through modulating BDNF/PI3K/Akt/GSK-3ß signaling in mice. Int. J. Mol. Sci. 2018, 19, 341. [CrossRef] [PubMed] 